\title{
URBAN SERVICES IN DEVELOPING COUNTRIES
}


Also edited by Dennis A. Rondinelli and G. Shabbir Cheema

DECENTRALIZATION AND DEVELOPMENT: Policy Implementation in Developing Countries

Also by Dennis A. Rondinelli

URBAN AND REGIONAL DEVELOPMENT PLANNING: Policy and Administration

PLANNING DEVELOPMENT PROJECTS (Editor)

URBANIZATION AND RURAL DEVELOPMENT: A Spatial Policy for Equitable Growth (with Kenneth Ruddle)

SECONDARY CITIES IN DEVELOPING COUNTRIES: Policies for Diffusing Urbanization

TRANSFORMING NATURAL RESOURCES FOR HUMAN DEVELOPMENT (with Kenneth Ruddle)

DEVELOPMENT PROJECTS AS POLICY EXPERIMENTS: An Adaptive Approach to Development Administration

APPLIED METHODS OF REGIONAL ANALYSIS: The Spatial Dimensions of Development Policy

DEVELOPMENT ADMINISTRATION AND US FOREIGN AID POLICY 


\section{Urban Services in Developing Countries}

Public and Private Roles in Urban Development

\section{Edited by}

Dennis A. Rondinelli

and

G. Shabbir Cheema

Foreword by Hidehiko Sazanami

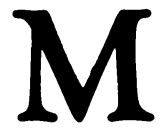


(C) The United Nations 1988

A shorter version of Chapter 2 appeared in

Public Administration and Development, vol. 6, no. 1, (C) 1986, and is reprinted here by permission of John Wiley \& Sons Ltd.

All rights reserved. No reproduction, copy or transmission of this publication may be made without written permission.

No paragraph of this publication may be reproduced, copied or transmitted save with written permission or in accordance with the provisions of the Copyright Act 1956 (as amended), or under the terms of any licence permitting limited copying issued by the Copyright Licensing Agency, 33-4 Alfred Place, London WC1E 7DP.

Any person who does any unauthorised act in relation to this publication may be liable to criminal prosecution and civil claims for damages.

First published 1988

Published by

THE MACMILLAN PRESS LTD

Houndmills, Basingstoke, Hampshire RG21 2XS

and London

Companies and representatives

throughout the world

British Library Cataloguing in Publication Data

Urban services in developing countries:

public and private roles in urban

development.

1. Public welfare-Developing countries

2. Cities and towns-Developing countries

I. Rondinelli, Dennis A. II. Cheema, G.

Shabbir

361'.91724 HV525

ISBN 978-0-333-61563-8

ISBN 978-1-349-13484-7 (eBook)

DOI 10.1007/978-1-349-13484-7 


\section{Contents}

List of Tables and Figures

vii

Foreword by Hidehiko Sazanami ix

Notes on the Contributors $\quad$ xi

1 Urban Services for the Poor: An Introduction Dennis A. Rondinelli and G. Shabbir Cheema

2 Increasing the Access of the Poor to Urban Services: Problems, Policy Alternatives and Organisational Choices

Dennis A. Rondinelli

3 Financing Urban Services in Developing Countries Ved Prakash

4 The Informal Service Sector as an Administrative Resource

John D. Montgomery

5 Replicating Urban Shelter Programmes: Problems and Challenges

Michael A. Cohen

6 Urban Service Provision in a Plural Society: Approaches in Malaysia

Lim Hong Hai

7 Social Services Programmes for the Poor in a Newly Industrialising Country: Experience in South Korea In-Joung Whang

8 Upgrading an Urban Squatter Settlement in Nigeria: The Experiment in Olaleye-Iponri

Paulina K. Makinwa-Adebusoye 
9 Providing Credit to Small Firms through Private Voluntary Organisations: UNO in Recife, Brazil Judith Tendler

10 Services for the Urban Poor: Policy Responses in Developing Countries

G. Shabbir Cheema

Index 


\section{List of Tables and Figures}

\section{TABLES}

2.1 Projected changes in number of poor households, rural and urban 1975-2000

2.2 Policy alternatives, programme implications and organisational focus for increasing access of the poor to urban services

3.1 Per capita gross national product in selected developing countries in Asia

3.2 Per capita total current revenue and tax receipts in selected countries in 1975

3.3 Local tax levies in selected developing countries in Asia

4.1 Services appropriate to the informal sector

4.2 Services appropriate for municipal action

4.3 Comparative advantage of central governments in urban services

4.4 Toward an optimal distribution of responsibility for services to the urban poor

6.1 The NADI programme: budget allocation and expenditure under the Fourth Malaysia Plan, 1981-5

8.1 Housing conditions in selected areas of metropolitan Lagos

8.2 Responsibilities of the participating agencies and Groups

9.1 UNO: loans, loan value, and expenditures, 1973-82

9.2 UNO: total and repeat loans, Recife and interior programmes, 1973-82

9.3 Sources of UNO's operating budget, 1973-82

10.1 Estimates of urban population in less developed countries by size-groups

10.2 Proportion of squatters and slum dwellers in selected cities

10.3 Types of organisational structures in selected cities

\section{FIGURE}

1.1 A framework for analysing urban service policies and programmes 


\section{Foreword}

The rapid pace of urbanisation in developing countries has increased the demand for urban services. But in most countries, the supply of shelter and basic urban services has not kept pace with demand. In particular, the urban poor do not have an adequate access to shelter and services such as water supply, sewage systems, low-cost housing, education and public health. Therefore, the effective management of shelter and urban services for the poor is being increasingly emphasised by planners and practitioners in developing countries, international organisations and donor countries. It is widely recognised that in order to increase our understanding of the needs of the urban poor and assist policy-makers in identifying appropriate programmes and projects, we must know more about physical and social characteristics of low-income settlements, the impact of past government projects, the appropriateness of management systems, and the mechanisms for participation of beneficiaries in the process of providing services to the urban poor.

The United Nations Centre for Regional Development (UNCRD) has initiated a cross-national research project on Managing Urban Development: Focus on Services for the Poor. The Centre has organised Expert Group Meetings to discuss concept papers commissioned by the Centre; and to prepare a research format for undertaking comparable case studies of urban projects. This book includes the revised version of those concept papers.

The book deals with an issue of growing importance: alternative means of providing basic services to the growing numbers of the poor in cities of the developing world. The chapters examine both policy issues and actual experiences with pioneering programmes in developing countries. They focus on the roles of government, community organisations and international agencies such as USAID, the World Bank and UNICEF. Problems of organisation and management, finance, social services, housing, slum upgrading and credit provision for small-scale businesses are highlighted.

A large number of experts from developing countries, international organisations and developed countries have collaborated with UNCRD on this project. I am particularly grateful to the contributors to this book for revising their papers for publication, Dennis A. Rondinelli and G. Shabbir Cheema for editing the papers, and 
UNICEF East Asia and Pakistan Regional Offices for providing part of the financial support.

I am confident that the volume will be of great interest to planners, scholars, and development practitioners concerned with providing shelter and basic urban services in low-income settlements and will lead to a better understanding of the process of managing povertyoriented urban projects in developing countries.

Hidehiko SaZANAMI Director, UNCRD 


\section{Notes on the Contributors}

G. Shabbir Cheema is Development Administration Planner, United Nations Center for Regional Development, Nagoya, Japan.

Michael A. Cohen is on the staff of the South Asia Regional Division of the World Bank in Washington, DC.

Lim Hong Hai is on the faculty of the School of Social Sciences at the Universiti Sains Malaysia in Penang, Malaysia.

Paulina K. Makinwa-Adebusoye is Associate Research Professor with the Centre for Social, Cultural and Environmental Research at the University of Benin in Nigeria.

John D. Montgomery is Professor of Public Administration, the John F. Kennedy School of Government, Harvard University.

Ved Prakash is Professor of Urban and Regional Planning at the University of Wisconsin, Madison.

Dennis A. Rondinelli is Senior Policy Analyst, Office for International Programs, at the Research Triangle Institute, Research Triangle Park, North Carolina.

Judith Tendler is Professor of Political Economy in the Department of Urban Studies and Planning at the Massachusetts Institute of Technology.

In-Joung Whang is Director of the International Development Research Program at the Korea Development Institute (KDI) in Seoul, Korea. 